\title{
Reporting Multiple Individual Injuries in Studies of Team Ball Sports: A Systematic Review of Current Practice
}

\author{
Lauren V. Fortington ${ }^{1} \cdot$ Henk van der Worp ${ }^{2}$ - Inge van den Akker-Scheek ${ }^{2}$. \\ Caroline F. Finch ${ }^{1}$
}

Published online: 26 October 2016

(C) The Author(s) 2016. This article is published with open access at Springerlink.com

\begin{abstract}
Background To identify and prioritise targets for injury prevention efforts, injury incidence studies are widely reported. The accuracy and consistency in calculation and reporting of injury incidence is crucial. Many individuals experience more than one injury but multiple injuries are not consistently reported in sport injury incidence studies. Objective The aim of this systematic review was to evaluate current practice of how multiple injuries within individuals have been defined and reported in prospective, long-term, injury studies in team ball sports.

Data Sources A systematic search of three online databases for articles published before 2016 .

Study Selection Publications were included if (1) they collected prospective data on musculoskeletal injuries in individual participants; (2) the study duration was $>1$ consecutive calendar year/season; and (3) individuals were the unit of analysis.

Data Extraction Key study features were summarised, including definitions of injury, how multiple individual injuries were reported and results relating to multiple injuries.
\end{abstract}

Electronic supplementary material The online version of this article (doi:10.1007/s40279-016-0637-3) contains supplementary material, which is available to authorized users.

Lauren V. Fortington

1.fortington@federation.edu.au

1 Australian Collaboration for Research into Injury in Sport and its Prevention (ACRISP), Federation University

Australia, SMB Campus, PO Box 663, Ballarat, VIC 3353, Australia

2 Center for Sports Medicine, University of Groningen, University Medical Center Groningen, Groningen, The Netherlands
Results Of the 71 publications included, half did not specifically indicate multiple individual injuries; those that did were largely limited to reporting recurrent injuries. Eight studies reported the number/proportion of athletes with more than one injury, and 11 studies presented the mean/number of injuries per athlete.

Conclusions Despite it being relatively common to collect data on individuals across more than one season, the reporting of multiple injuries within individuals is much more limited. Ultimately, better addressing of multiple injuries will improve the accuracy of injury incidence studies and enable more precise targeting and monitoring of the effectiveness of preventive interventions.

\section{Key Points}

While there is an increasing awareness of and increasing number of publications that report the collection of individual injury data across more than one season/year, the reporting of this injury data appears to be challenging.

Half of the publications identified reported the total number of injuries or injured athletes as an overall grouped result across the entire study duration.

Studies that recognised multiple individual injuries were largely limited to reporting recurrent injuries (of the exact same type and side).

Injury prevention efforts rely on accurate incidence estimates, and ongoing developments toward better reporting of multiple injuries is encouraged. 


\section{Introduction}

For people who participate in team ball sports, injuries can unfortunately be a common occurrence. Reducing the chance of sustaining an injury is of importance for athletes, team support staff (e.g. coaches and trainers) and sports/health bodies, not only for individual health protection but also for broader benefits, such as better team performance $[1,2]$ and encouraging continued participation in sport [3]. Investigation of injury incidence is the basis of injury prevention as it is needed to identify the sports, injury types or risk factors (e.g. intrinsic and extrinsic risks) that need to be targeted for prevention, as well as to monitor the effectiveness of implemented interventions [4-8]. It follows that accuracy and consistency in the calculation and reporting of injury incidence, upon which these priorities are based, is crucial.

Consensus statements for injury surveillance in some sports [9-11] have been published in an effort to guide the accuracy and consistency of injury reporting sought across studies. Methodological papers have also been published with clear definitions and explanations of the different sports injury epidemiological terms [12] and how to interpret or apply them $[6,7,13,14]$. In short, to facilitate comparison across different sports, settings and follow-up periods, a common measure used to describe the frequency of injury is the incidence proportion, which is essentially the number of new injuries sustained in a defined population (inclusive of the injured person) over a specified period of time. In a sports-injury context, the numerator is generally the number of injuries or number of injured athletes, while the denominator/time component is often reported as the total number of athletic exposures or hours played during the follow-up period.

One of the major challenges in sports injury research is that many athletes experience multiple injuries, therefore contributing to the numerator of injury rates more than once [7]. Where more than one injury is experienced, the terms 'index injury' for the first injury and 'subsequent injury' for injuries that follow can be used to differentiate injuries in a time-ordered sequence [15]. Where the same body part is injured repeatedly, and is classified as having the same nature, injuries are commonly referred to as being 'recurrent' [11, 15-17]. Some subsequent injuries will have a clear biomechanical relation to an initial index injury (e.g. recurrent left-side ankle sprains), while others may be indirectly linked (e.g. calf injury leads to an ankle sprain). Subsequent injuries may also occur due to situational relationships (e.g. smaller player continues to collide with taller, heavier opposition player), or there may be no identifiable relationship to the initial index injury.

The delineation of multiple injuries is vital to the accuracy of determining injury incidence, with incorrect estimates arising if statistical dependencies across injuries are not properly accounted for $[7,18,19]$. The number of (subsequent) injuries is dependent on how injuries are defined (e.g. a new injury, a recurrent injury, first injury, etc.), the method of injury registration (e.g. self-reported, clinical diagnosis), data collection approach (e.g. prospective or retrospective), and length of follow-up (e.g. one season/year only or continued data collection, with longer follow-up having a higher likelihood of more than one injury). Most prospective injury studies have limited their data collection to one sports season only, although it is likely that injury incidence varies over seasons [19]. Moreover, it is possible that injury occurrences across seasons are related to injuries in an earlier season $[15,19]$. The risk of injury is generally considered to be higher in people who have had a previous injury, with reasons thought to be related to residual tissue weaknesses, the athlete's sport, position or behaviour presenting an inherent risk, or the individual returning to sport before complete recovery of an injury $[15,20]$. Increased sporting experience has also been shown to reduce injury risk, perhaps owing to better developed physical conditioning or maturity in match play [21,22]. What is most clear is that there is likely to be an altered risk of future injury over time, particularly for previously injured athletes [19].

The aim of this systematic review is to consider how multiple injuries sustained by individuals have been defined and reported in prospective, long-term (more than one consecutive year or season), injury incidence studies. The review is focused on team ball sports as these sports are often prioritised for injury prevention globally due to large numbers of injuries and participants, and there is a substantial body of literature reporting injury incidence. With the information extracted from the selected studies, we describe whether, and how, multiple injuries within individuals have been addressed and reported. This is important because weaknesses in existing research need to be identified so that they can be addressed in future work through better study design, improved methodological considerations, enhancements to statistical analysis and reporting of injury data or refocussed clinician and researcher training.

\section{Methods}

\subsection{Search}

A search of the PubMed, Web of Science and Embase databases was performed, on the basis that the leading sports medicine journals are indexed within these databases. The full search strategy is described in electronic supplementary material Appendix S1. Studies that reported 
injury incidence in team ball sports for more than $1 \mathrm{cal}$ endar year or at least two consecutive seasons were included. As not all studies include keywords that consider duration of the study (i.e. we sought more than one season), the search strategy was initially kept broad and a relatively large number of publications screened to allow a specific check of inclusion dates in the full text. All articles were screened by two authors independently, using the criteria described below. Differences were discussed and when no consensus was obtained upon study inclusion, a third author adjudicated. No date restriction was placed for the beginning of the search, with studies included up to an end date of 31 December 2015. Where we could not locate an original paper from our resources, authors were directly contacted.

\subsection{Study Selection}

Articles were included if (1) they reported injury incidence (i.e. not specific to one injury type) over the time period (e.g. not game injuries only) because we were interested in multiple injuries, studies focusing on single injury types or those sustained in games only were deemed overly restrictive; (2) the study was conducted with participants of team ball sports; (3) data were collected prospectively; (4) the follow-up was more than 1 calendar year or over at least two consecutive seasons; (5) data were collected in a defined cohort (e.g. club, division, school, team, league); and (6) an individual identifier was clear in the collection of data (i.e. an ID or name that would allow the research team to potentially link more than one injury within individuals). The latter criterion was deemed crucial if the original authors had been able to report multiple injuries within an individual.

Non-English language articles, conference abstracts, commentaries and reviews were excluded. Studies based on hospital data were excluded because generally people do not always attend hospital with a sports injury, nor do they exclusively attend the same hospital, therefore such data cannot be used to confidently identify multiple injuries within individuals. Studies conducted during (multiple or consecutive) tournament-style competitions were also excluded as there are often long time frames between such competitions and athletes are likely to participate in other competitions/events over the period during which their injury risk exposures and outcomes would be unaccounted. Where more than one publication was presented from the same source study/dataset, we initially included all publications identified (that met all inclusion criteria) as different approaches may have been used to report/analyse data across papers; if the same data and analysis were reported (albeit for a different aim), only the earliest study published was kept and is presented with a note indicating subsequent publications. The exact number of publications excluded by different reasons is not provided as they were excluded on the first identified reason only (therein potentially presenting an inaccurate picture, as additional reasons, other than the first identified, could also apply).

\subsection{Data Extraction}

The following data were extracted from the articles, by two authors, into an Excel database. Relevant results were tabulated and presented, along with their descriptive information across five tables.

Descriptive information provided in Table 1 included:

- participant demographics (sex, age) and sport setting (sport, level of play, country/region)

- number of included athletes (or athlete-seasons or alternative)

- study duration and time frames

- study aim, summarised as the primary focus of the injury measure, being:

- incidence (number of injuries occurring in the population over time)

- risk (investigations of independent variables that contributed to the occurrence of the injury)

- incidence and injury risk in combination (with each defined in the same manner as incidence and risk separately)

- more than one injury (study was specifically looking at relationships between more than one individual injury occurrence)

- injury definition, coded according to Timpka et al. [23] as

- sports incapacity—performance/participation impacted on (commonly includes 'time loss injuries')

- sports injury — clinically observed injuries

- sports trauma—self-reported injuries by athletes

- identification of multiple individual injuries in results (reported within the publication-yes or no)

- severity or duration of injury where relevant to the definition, i.e. sport incapacity with 24-h time loss or the minimum number of games missed.

From publications that presented pooled (grouped) injury results, the number of injuries and number of injured participants were summarised, demonstrating that there was more than one injury occurrence by individuals in these studies (Table 2). Where injury data were presented on a per-person basis (i.e. not only presenting pooled injury results for an entire group), additional information was extracted on how individual injury data were presented, the 


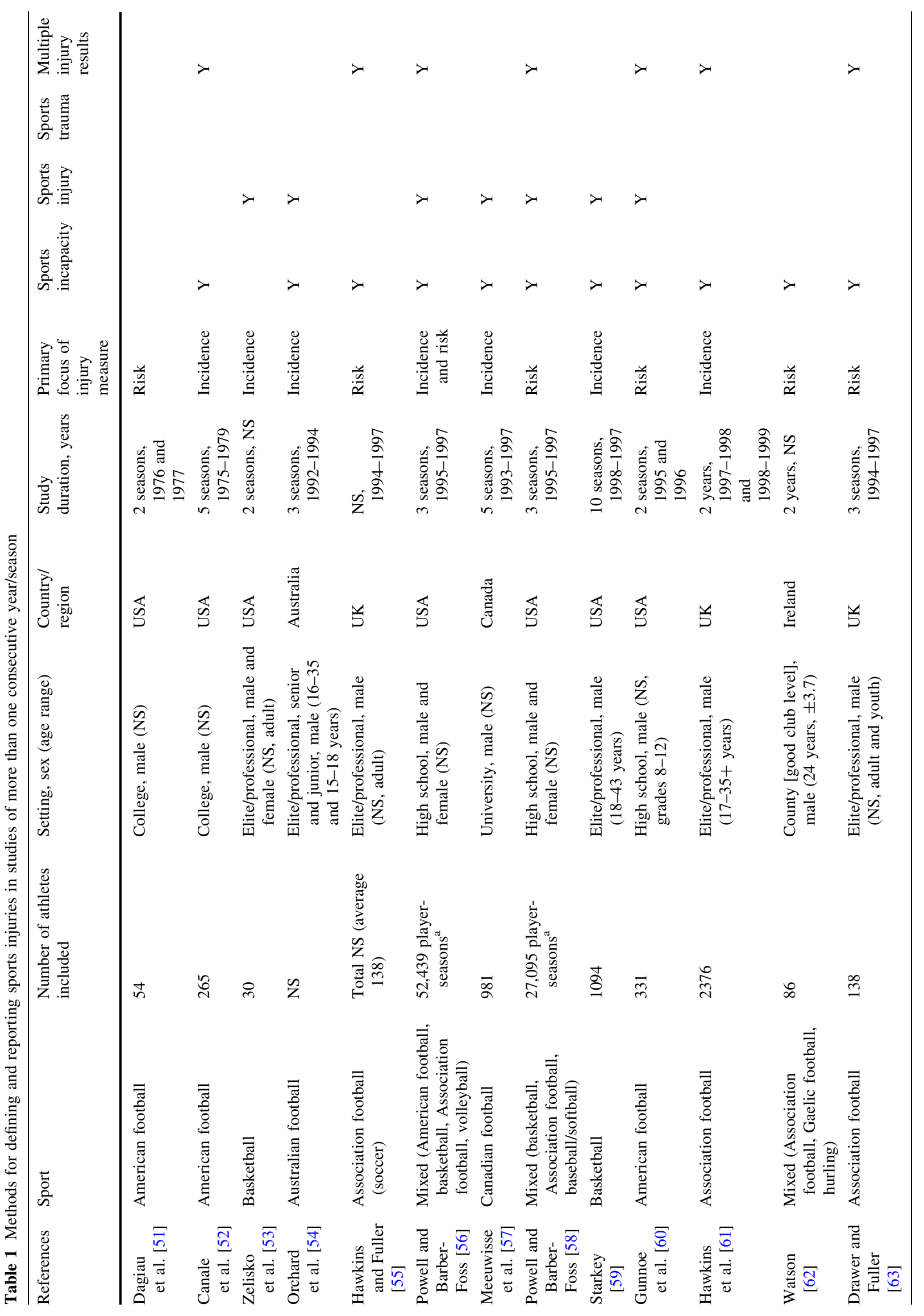




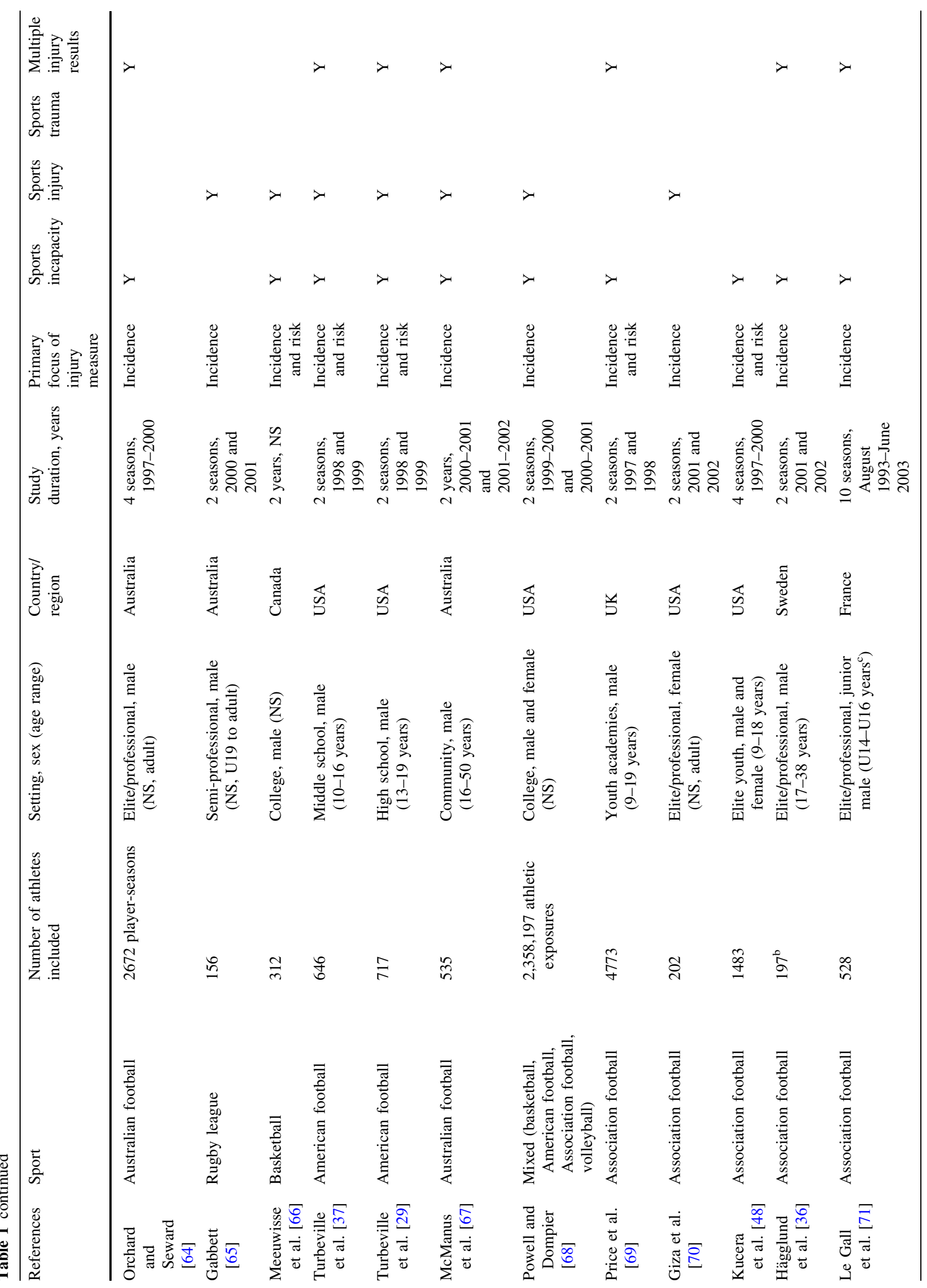




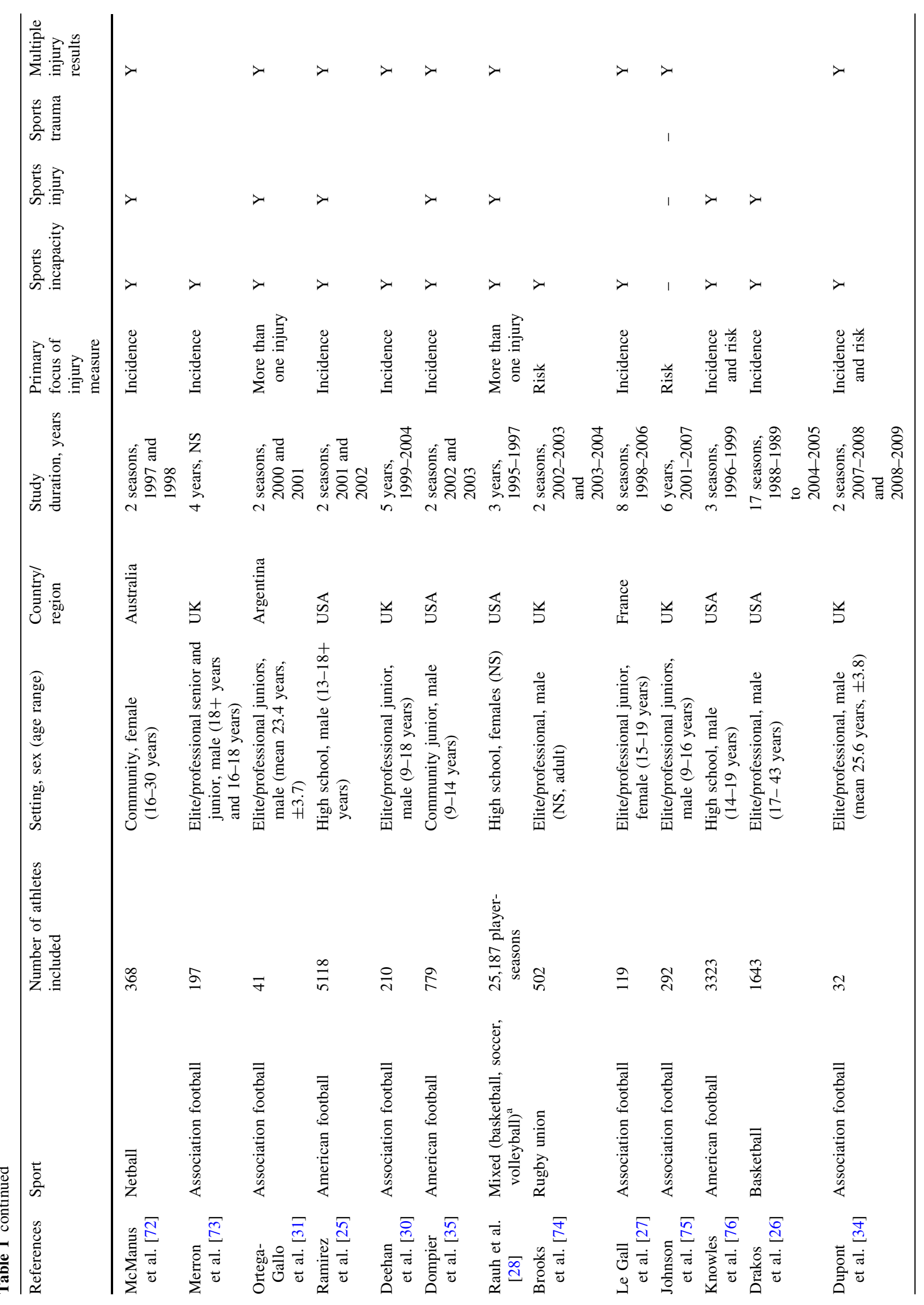




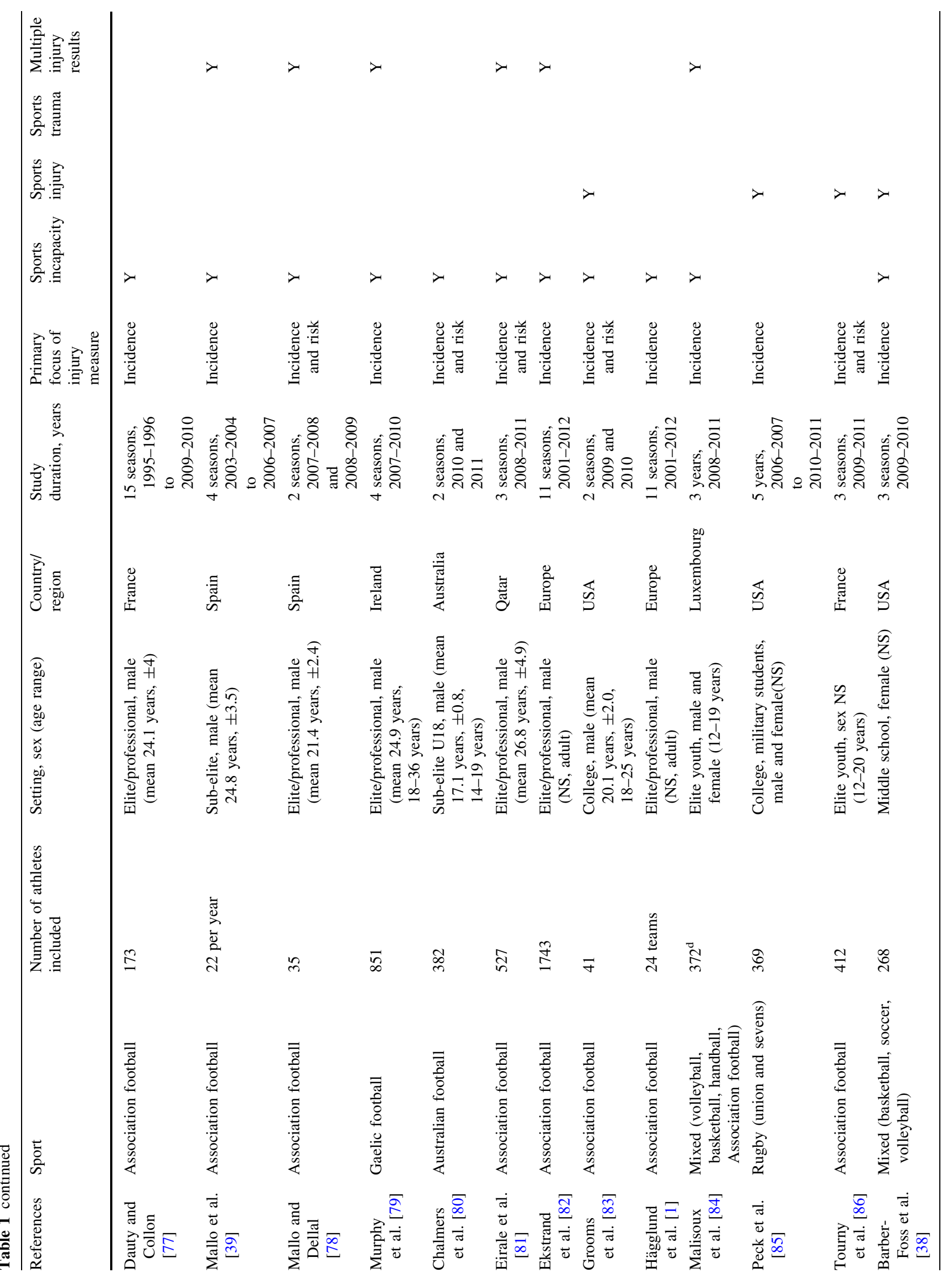




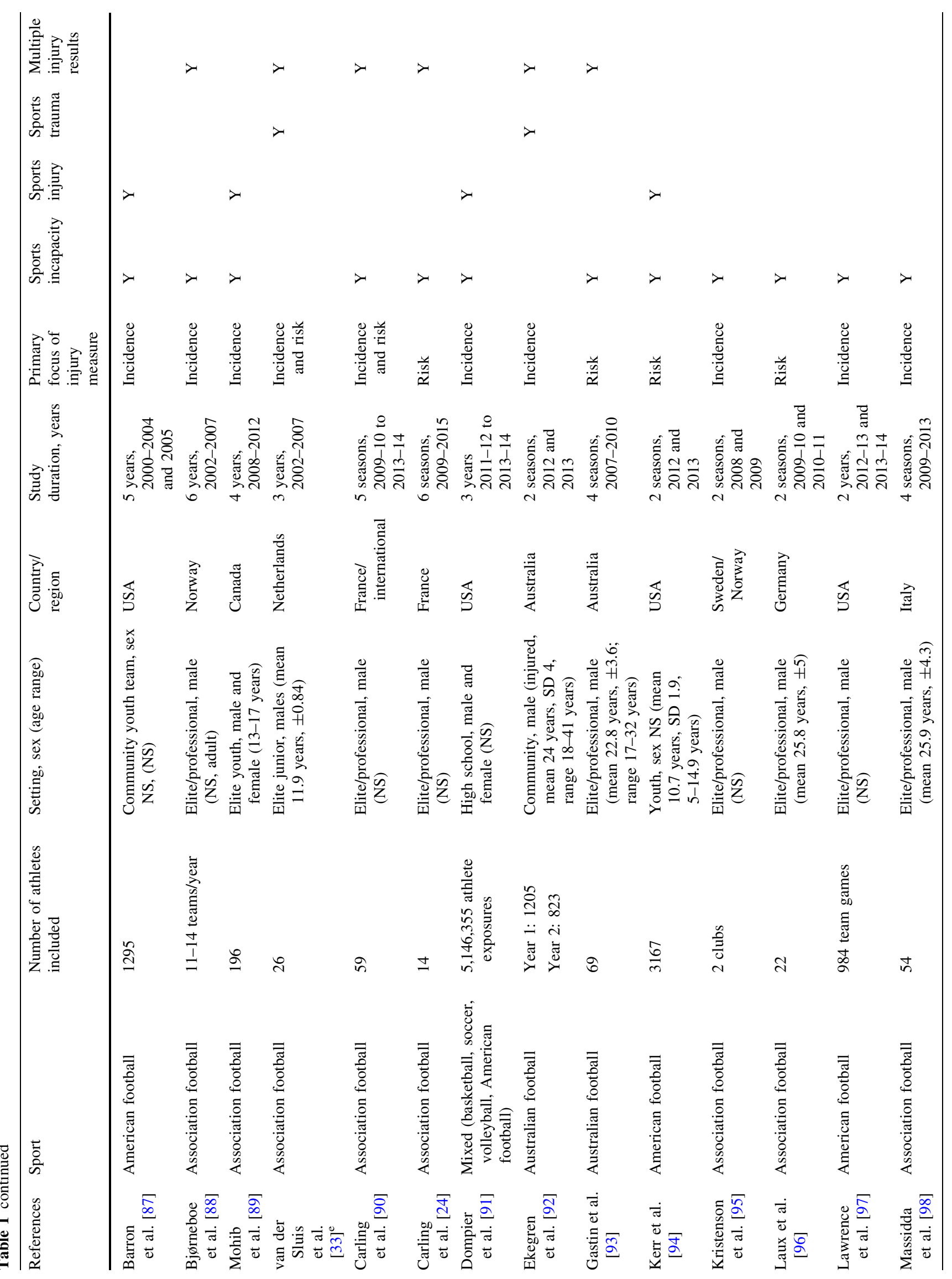




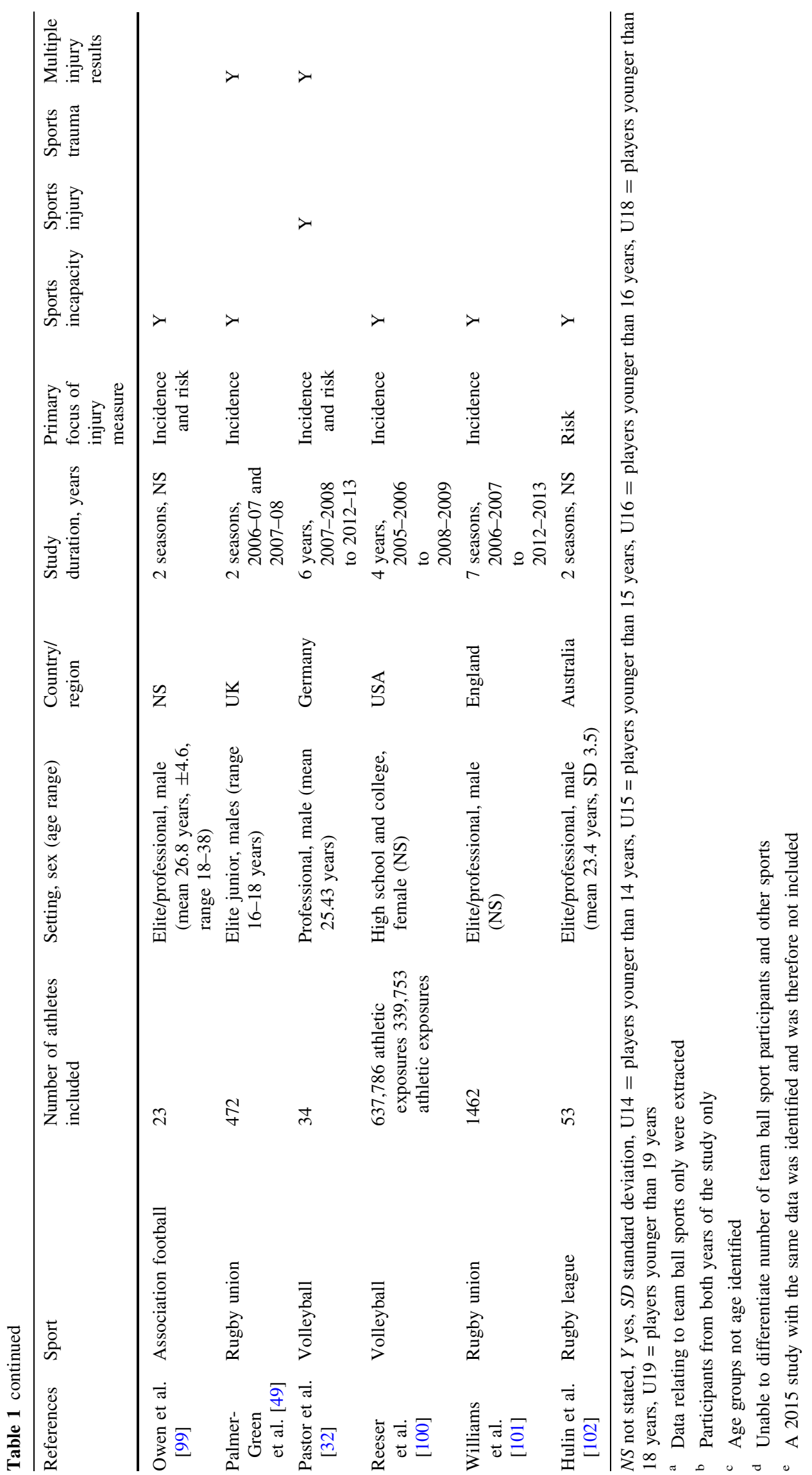


Table 2 Number of injuries, athletes and injured athletes in studies that did not specifically report multiple injury occurrences

\begin{tabular}{|c|c|c|c|c|c|}
\hline References & Number of injuries reported & $\begin{array}{l}\text { Number of } \\
\text { athletes } \\
\text { included }\end{array}$ & $\begin{array}{l}\text { Injured athletes } \\
(n \text { or } \%)\end{array}$ & $\begin{array}{l}\text { Number of injuries greater } \\
\text { than the number of included } \\
\text { athletes }\end{array}$ & $\begin{array}{l}\text { Number of injuries greater } \\
\text { than the number of injured } \\
\text { athletes }\end{array}$ \\
\hline $\begin{array}{l}\text { Dagiau } \\
\text { et al. [51] }\end{array}$ & 129 & 54 & Not reported & $\mathrm{Y}$ & - \\
\hline $\begin{array}{l}\text { Zelisko } \\
\text { et al. [53] }\end{array}$ & 272 & 30 & Not reported & $\mathrm{Y}$ & - \\
\hline $\begin{array}{l}\text { Orchard } \\
\text { et al. [54] }\end{array}$ & 4065 & NS & Not reported & - & - \\
\hline $\begin{array}{l}\text { Meeuwisse } \\
\text { et al. [57] }\end{array}$ & $\begin{array}{l}1811 \text { injury-events (1971 distinct } \\
\text { injuries) }\end{array}$ & 981 & $\begin{array}{l}\text { Range } \\
53.5-60.4 \% \\
\text { (different } \\
\text { years) }\end{array}$ & $\mathrm{Y}$ & - \\
\hline $\begin{array}{l}\text { Starkey } \\
\text { [59] }\end{array}$ & $\begin{array}{l}7449 \text { athletic-related injuries } \\
\text { (9904 inclusive of all reported } \\
\text { injuries/illnesses) }\end{array}$ & 1094 & $\begin{array}{l}961 \text { (all } \\
\text { reported } \\
\text { injury/illness) }\end{array}$ & $\mathrm{Y}$ & $\mathrm{Y}$ \\
\hline $\begin{array}{c}\text { Watson } \\
{[62]}\end{array}$ & NA (mean days of injury reported) & 86 & Not reported & - & - \\
\hline $\begin{array}{c}\text { Gabbett } \\
{[65]}\end{array}$ & 2253 & 156 & Not reported & $\mathrm{Y}$ & - \\
\hline $\begin{array}{l}\text { Meeuwisse } \\
\text { et al. [66] }\end{array}$ & 215 & 312 & 142 & $\mathrm{~N}$ & $\mathrm{Y}$ \\
\hline $\begin{array}{l}\text { Powell and } \\
\text { Dompier } \\
{[68]}\end{array}$ & 68,497 & $\begin{array}{l}2,358,197 \\
\text { athletic } \\
\text { exposures }\end{array}$ & Not reported & $\mathrm{N}$ & - \\
\hline $\begin{array}{l}\text { Giza et al. } \\
\text { [70] }\end{array}$ & 173 & 202 & 110 & $\mathrm{Y}$ & $\mathrm{Y}$ \\
\hline $\begin{array}{l}\text { Kucera } \\
\text { et al. [48] }\end{array}$ & 787 & 1483 & $40.7 \%$ & $\mathrm{~N}$ & $\mathrm{~N}$ \\
\hline $\begin{array}{l}\text { Merron } \\
\text { et al. [73] }\end{array}$ & 427 & 197 & 195 & $\mathrm{Y}$ & $\mathrm{Y}$ \\
\hline $\begin{array}{l}\text { Brooks } \\
\text { et al. [74] }\end{array}$ & 1475 & 502 & Not reported & $\mathrm{Y}$ & - \\
\hline $\begin{array}{l}\text { Knowles } \\
\text { et al. [76] }\end{array}$ & 1238 & 3323 & 1064 & $\mathrm{~N}$ & $\mathrm{Y}$ \\
\hline $\begin{array}{l}\text { Drakos } \\
\text { et al. [26] }\end{array}$ & 12,594 & 1643 & Not reported & $\mathrm{Y}$ & - \\
\hline $\begin{array}{l}\text { Dauty and } \\
\text { Collon } \\
{[77]}\end{array}$ & 903 & 173 & Not reported & Y & - \\
\hline $\begin{array}{l}\text { Chalmers } \\
\text { et al. [80] }\end{array}$ & 232 & 382 & Not reported & $\mathrm{N}$ & - \\
\hline $\begin{array}{l}\text { Grooms } \\
\text { et al. [83] }\end{array}$ & 17 & 41 & Not reported & $\mathrm{N}$ & - \\
\hline $\begin{array}{l}\text { Hägglund } \\
\text { et al. [1] }\end{array}$ & 7792 & 24 teams & Not reported & - & - \\
\hline $\begin{array}{l}\text { Peck et al. } \\
\text { [85] }\end{array}$ & 659 & 369 & 222 & $\mathrm{Y}$ & Y \\
\hline $\begin{array}{l}\text { Tourny } \\
\text { et al. [86] }\end{array}$ & 618 & 412 & Not reported & $\mathrm{Y}$ & - \\
\hline $\begin{array}{l}\text { Barber- } \\
\text { Foss et al. } \\
{[38]}\end{array}$ & 134 & 268 & Not reported & $\mathrm{N}$ & - \\
\hline $\begin{array}{l}\text { Barron } \\
\text { et al. [87] }\end{array}$ & 694 & 1295 & Not reported & $\mathrm{N}$ & - \\
\hline
\end{tabular}


Table 2 continued

\begin{tabular}{|c|c|c|c|c|c|}
\hline References & Number of injuries reported & $\begin{array}{l}\text { Number of } \\
\text { athletes } \\
\text { included }\end{array}$ & $\begin{array}{l}\text { Injured athletes } \\
(n \text { or } \%)\end{array}$ & $\begin{array}{l}\text { Number of injuries greater } \\
\text { than the number of included } \\
\text { athletes }\end{array}$ & $\begin{array}{l}\text { Number of injuries greater } \\
\text { than the number of injured } \\
\text { athletes }\end{array}$ \\
\hline $\begin{array}{l}\text { Mohib } \\
\text { et al. [89] }\end{array}$ & 733 & 196 & Not reported & $\mathrm{Y}$ & - \\
\hline $\begin{array}{l}\text { Dompier } \\
\text { et al. [91] }\end{array}$ & 47,014 & $\begin{array}{l}5,146,355 \\
\text { athlete } \\
\text { exposures }\end{array}$ & Not reported & - & - \\
\hline $\begin{array}{l}\text { Kerr et al. } \\
\text { [94] }\end{array}$ & 1475 & 3167 & 915 & $\mathrm{~N}$ & $\mathrm{Y}$ \\
\hline $\begin{array}{l}\text { Kristenson } \\
\text { et al. [95] }\end{array}$ & 323 & 2 clubs & Not reported & - & - \\
\hline $\begin{array}{l}\text { Laux et al. } \\
\text { [96] }\end{array}$ & 44 & 22 & Not reported & Y & - \\
\hline $\begin{array}{l}\text { Lawrence } \\
\text { et al. [97] }\end{array}$ & 4284 & $\begin{array}{l}984 \text { team } \\
\text { games }\end{array}$ & 1172 & - & $\mathrm{Y}$ \\
\hline $\begin{array}{l}\text { Massidda } \\
\text { et al. [98] }\end{array}$ & $\begin{array}{l}\text { NA (mean injury incidence by } \\
\text { subgroups reported) }\end{array}$ & 54 & Not reported & - & - \\
\hline $\begin{array}{l}\text { Owen et al. } \\
\text { [99] }\end{array}$ & 119 & 23 & Not reported & $\mathrm{Y}$ & - \\
\hline \multirow[t]{2}{*}{$\begin{array}{l}\text { Reeser } \\
\text { et al. } \\
{[100]}\end{array}$} & $\begin{array}{l}792 \text { (high school) } \\
1380 \text { (college) }\end{array}$ & $\begin{array}{l}637,786 \\
\text { athletic } \\
\text { exposures }\end{array}$ & Not reported & - & - \\
\hline & & $\begin{array}{l}339,753 \\
\text { athletic } \\
\text { exposures }\end{array}$ & & & \\
\hline $\begin{array}{c}\text { Williams } \\
\text { et al. } \\
\text { [101] }\end{array}$ & 6967 & 1462 & Not reported & $\mathrm{Y}$ & - \\
\hline $\begin{array}{l}\text { Hulin et al. } \\
\text { [102] }\end{array}$ & 205 & 53 & Not reported & $\mathrm{Y}$ & - \\
\hline
\end{tabular}

$Y$ yes, $N$ no, $N S$ not stated, $N A$ not applicable, - indicates not able to be answered by data presented in study

number of injuries, and the number of individuals injured (Tables 3, 4, 5).

\section{Results}

After removing duplicates, the search resulted in 7630 studies. The majority of these studies were excluded after reading the abstract, with 235 full-text publications retrieved for detailed reviewed (see Fig. 1). Based on information in the full-text of publications, a further 164 papers were excluded because they had less than 1 year of data collection, collected data at a team level not an individual level, were not full original research papers or did not cover all injuries (e.g. focusing only on match injuries or knee injuries). Overall, 71 publications were retained for analysis.

The studies covered a range of different sports and settings (Table 1), with between 14 [24] and 5118 [25] individual participants reported. Twelve studies presented participant inclusion without individuals, but rather as the number of teams per year or the total number of athlete-seasons combined. Not all participants/teams were followed for the full duration of a study and it was uncommon for authors to report specific follow-up times of individuals/teams. Studies were conducted over a minimum of two seasons/years (in line with our inclusion criteria), to a maximum of 17 consecutive years [26]. Almost one-quarter $(n=16,23 \%)$ of included studies were published in 2015 or later.

Summarising the broad aim of the papers, half $(n=39$ of $71,55 \%$ ) were aimed at reporting the incidence of injury, one-quarter $(n=17,24 \%)$ reported both injury incidence and injury risk, $18 \%(n=13)$ were focused on the risk of injury alone, and $3 \%(n=2)$ were aimed at investigating more than one injury occurrence.

Injury definitions were most commonly based around the Timpka et al. [23] domain of sports incapacity (Table 1). Sports incapacity was often used in combination with a specified definition from the sports injuries domain (a clinically observed injury) wherein certain diagnoses 
Table 3 Proportion of athletes with recurrent injuries (same type, same site) identified in studies reporting injury recurrence ( $n=20$ studies)

\begin{tabular}{lllll}
\hline References & $\begin{array}{l}\text { Follow-up } \\
\text { (years) }\end{array}$ & $\begin{array}{l}\text { Sports incapacity definition (duration } \\
\text { of incapacity/injury inclusion) }\end{array}$ & $\begin{array}{l}\text { Recovery } \\
\text { definition }\end{array}$ & $\begin{array}{l}\% \text { of injuries } \\
\text { classified } \\
\text { as 'recurrent/re- } \\
\text { injuries' }\end{array}$ \\
\hline
\end{tabular}

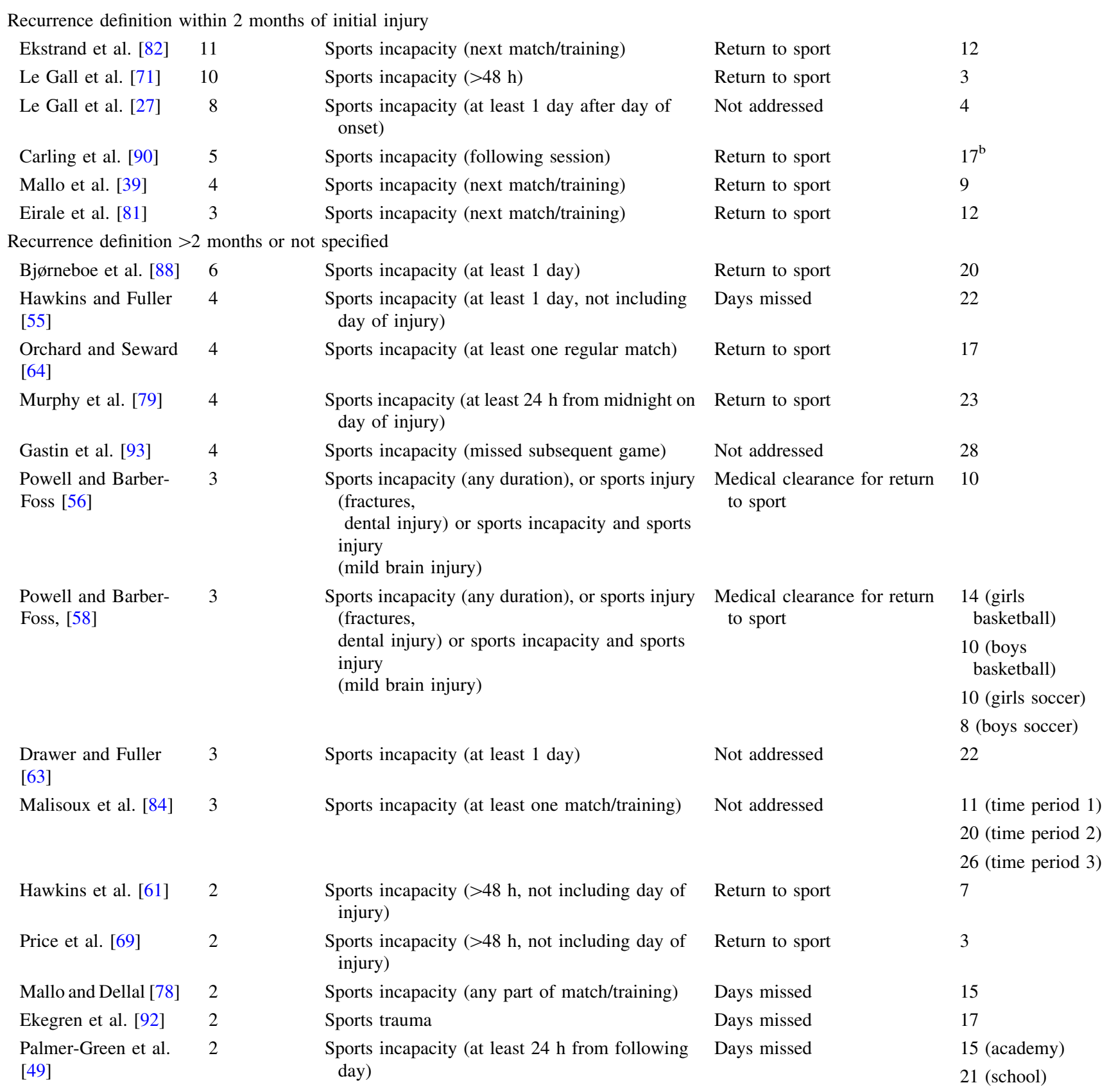

${ }^{a}$ Definitions from Timpka et al. [47]

${ }^{\mathrm{b}}$ Only recurrences sustained while participating in a national team were reported

(e.g. fractures, dislocations) were included, irrespective of the incapacity incurred. For example, the definition may have read similar to 'injuries that resulted in over $24 \mathrm{~h}$ of time loss, as well as all fractures and dislocations'.
Keeping in mind the inclusion criteria that an individual identifier was clear in the collection of data, almost half ( $n=34$ of $71,48 \%$ ) of the studies did not report the number or distribution of multiple individual injuries 
Table 4 Summary of the proportion of athletes with more than one injury (from the total included and injured only) [ $n=8$ studies]

\begin{tabular}{|c|c|c|c|c|c|c|c|c|c|}
\hline References & $\begin{array}{l}\text { Follow- } \\
\text { up } \\
\text { (years) }\end{array}$ & $\begin{array}{l}\text { Number } \\
\text { of } \\
\text { athletes } \\
\text { included }\end{array}$ & $\begin{array}{l}\text { Number } \\
\text { of } \\
\text { injured } \\
\text { athletes }\end{array}$ & $\begin{array}{l}\text { Number } \\
\text { of injuries }\end{array}$ & $\begin{array}{l}\text { Number of } \\
\text { athletes with } \\
\text { more than } \\
\text { one injury }\end{array}$ & $\begin{array}{l}\% \text { of injured } \\
\text { athletes with } \\
\text { more than one } \\
\text { injury }\end{array}$ & $\begin{array}{l}\% \text { of all } \\
\text { included } \\
\text { athletes with } \\
\text { more than one } \\
\text { injury }\end{array}$ & $\begin{array}{l}\text { Average } \\
\text { number of } \\
\text { injuries per } \\
\text { included }_{\text {athlete }^{\mathrm{a}}}\end{array}$ & $\begin{array}{l}\text { Average } \\
\text { number of } \\
\text { injuries per } \\
\text { injured } \\
\text { athlete }^{b}\end{array}$ \\
\hline $\begin{array}{l}\text { Le Gall } \\
\text { et al. [27] }\end{array}$ & 8 & 119 & 110 & 619 & 99 & 90 & 83 & 5.2 & 5.6 \\
\hline \multicolumn{10}{|c|}{ Rauh et al. [28] } \\
\hline Basketball & 3 & - & 1271 & 1748 & 335 & 26 & - & & 1.4 \\
\hline Soccer & & - & 1258 & 1771 & 342 & 27 & - & & 1.4 \\
\hline Volleyball & & - & 580 & 701 & 100 & 17 & - & & 1.2 \\
\hline \multirow[t]{2}{*}{$\begin{array}{l}\text { McManus } \\
\text { et al. [72] }\end{array}$} & 1997 & 368 & 112 & $\begin{array}{l}\text { Minimum } \\
146\end{array}$ & 29 & 26 & 8 & & - \\
\hline & 1998 & & 160 & $\begin{array}{l}\text { Minimum } \\
258\end{array}$ & 70 & 44 & 19 & & - \\
\hline $\begin{array}{l}\text { McManus } \\
\text { et al. [67] }\end{array}$ & 2 & 535 & 400 & 1031 & 254 & 64 & 47 & 1.9 & 2.6 \\
\hline $\begin{array}{l}\text { Gunnoe } \\
\text { et al. [60] }\end{array}$ & 2 & 331 & 121 & 165 & 32 & 26 & 10 & 0.5 & 1.4 \\
\hline $\begin{array}{l}\text { Turbeville } \\
\text { et al. [29] }\end{array}$ & 2 & 717 & 100 & 132 & - & $17-26$ & - & 0.2 & 1.3 \\
\hline $\begin{array}{l}\text { Ramirez } \\
\text { et al. [25] }\end{array}$ & 2 & 5118 & 1307 & $1700^{\mathrm{c}}$ & 298 & 23 & 6 & 0.3 & 1.3 \\
\hline $\begin{array}{l}\text { Canale } \\
\text { et al. [52] }\end{array}$ & 5 & 265 & 227 & 283 & 51 & 22 & 19 & 1.1 & 1.2 \\
\hline
\end{tabular}

${ }^{a}$ Calculated as number of injuries/number of included athletes

${ }^{b}$ Calculated as number of injuries/number of injured athletes

c Total injury events (more than one diagnosis given to some events)

Table 5 Outcomes of included studies $(n=11)$ that have reported the number/mean injuries per athlete over time

\begin{tabular}{ll}
\hline References & Outcome \\
\hline Mean injuries per athlete per season & \\
Ortega-Gallo et al. [31] & 9.5 injuries per athlete per season \\
Le Gall et al. [71] & 2.2 injuries per athlete per season \\
Deehan et al. [30] & 0.6 injuries per athlete per season \\
Ekegren et al. [92] & 0.7 injuries per athlete per season (first and second seasons) \\
Mean injuries per athlete over study period & \\
Le Gall et al. [27] & 5.2 injuries per athlete \\
Mallo et al. [39] & $3.6 \pm 0.7$ injuries per athlete \\
Mallo and Dellal, [78] & $2.3 \pm 1.8$ injuries per athlete \\
Dupont et al. [34] & $5.2 \pm 3.7$ injuries per athlete \\
Pastor et al. [32] & 1.94 per athlete (acute injuries) \\
van der Sluis et al. [33] & 0.64 per athlete (overuse injuries) \\
Number of injuries per athlete per $1000 \mathrm{~h}$ & $6.85 \pm 5.46$ for the total group during the 3 years \\
Johnson et al. [75] & \\
\hline
\end{tabular}

within the study (Table 2). From these studies, the number of injured athletes could not be confirmed from data in 24 of 34 publications $(71 \%)$. The number of injuries exceeded the number of included athletes in 17 of 26 (65\%) papers in which the relevant injury and athlete numbers could be identified. Furthermore, the number of 
Fig. 1 Study selection and inclusion process

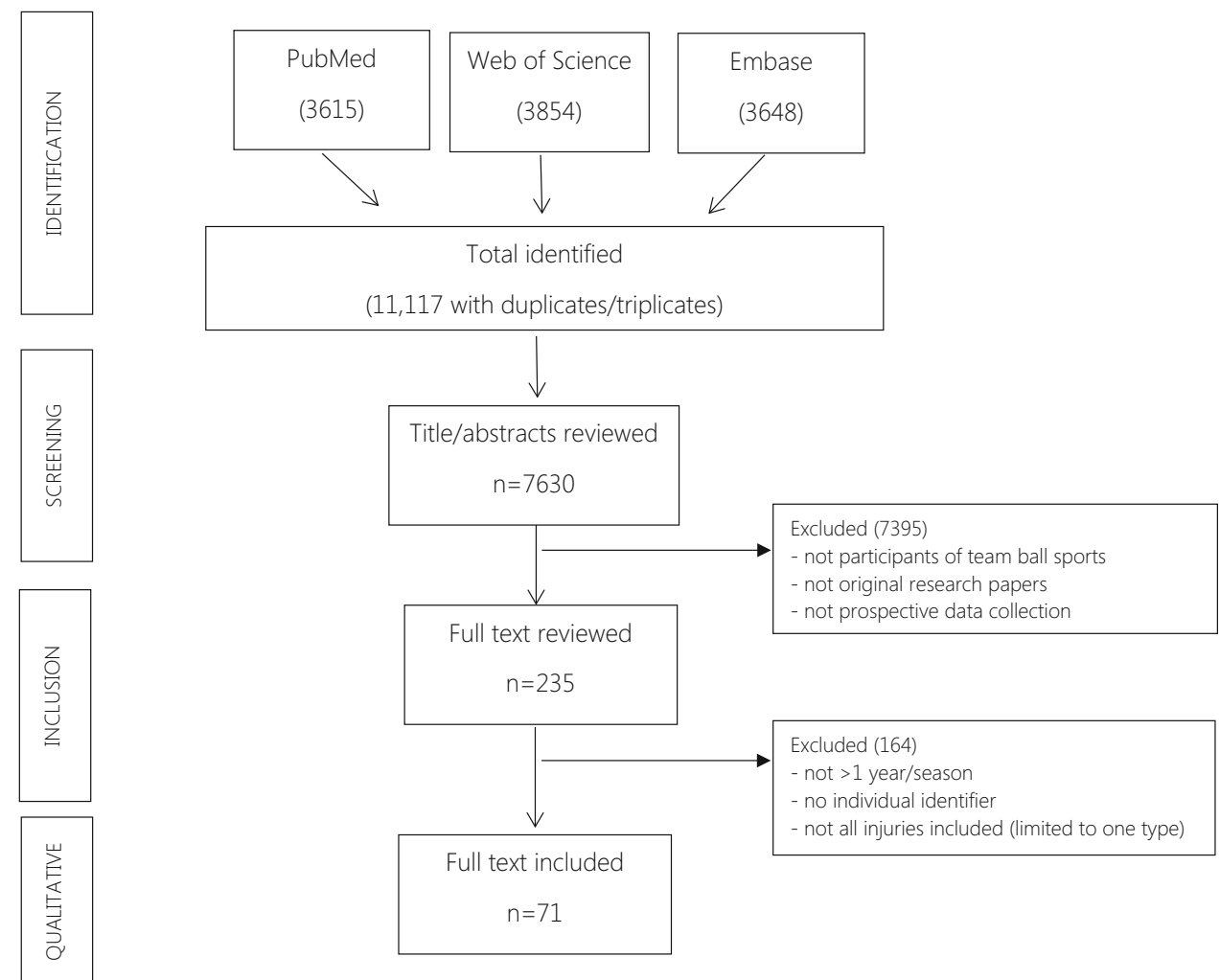

injuries exceeded the number of injured athletes in 8 of 9 papers $(89 \%)$ where relevant numbers could be identified. These two observations, in particular, indicate the presence of multiple injuries in some athletes.

Where multiple injuries were reported $(n=37$ of 71 , $52 \%)$, studies mostly addressed recurrent injuries only ( $n=20,28 \%$ of all studies, $59 \%$ of studies reporting multiple injury results) (Table 3 ). The proportion of recurrent injuries varied from as few as $3 \%$ of injuries to as many as $26 \%$, and was influenced by the injury definition, duration of the study, and recurrence criterion being within 2 months or greater than 2 months.

Eight studies (11\% of all studies, $22 \%$ of studies reporting multiple injury results) reported a frequency proportion of athletes who had sustained varying numbers of injuries (e.g. up to 8, or grouped as 3+) (Table 4). Results from each of these studies were collapsed to enable comparable presentation of the number and proportion of athletes with more than one injury. As a proportion of all included athletes, as few as $6 \%$ [25] and as many as $83 \%$ [27] of athletes had multiple injuries recorded within the study period. As a proportion of injured athletes, there were as few as $17 \%[28,29]$ and as many as $90 \%$ of athletes with more than one injury [27].

Eleven studies (15\% of all studies, $30 \%$ of studies reporting multiple injury results) presented the mean number of injuries per athlete for a specified time
(Table 5). A range of 0.6 [30] to 9.5 injuries [31] was observed when considered as an average per athlete per season. Looking at the mean per athlete over the whole study period, the range varied from 0.6 to 1.9 (injuries reported separately as overuse and acute, respectively [32]) to 6.9 injuries [33] per athlete over the study period.

In the included publications, other methods used to report multiple individual injuries included the numerical range of injury numbers sustained by an individual (e.g. Pastor et al. [32] and Dupont et al. [34]), the maximum number of injuries sustained by an individual (e.g. Dompier et al. [35]), the risk of injury in subsequent seasons (e.g. Rauh et al. [28] and Hägglund et al. [36]), or simply stating that some athletes had more than one injury during the season [37].

\section{Discussion}

Documenting injury incidence requires consistent and precise measures in order to accurately study risk factors for injury and to prioritise and monitor preventive interventions. Experiencing more than one injury is common in sports settings, and this presents challenges to the collection and reporting of injury incidence data. Different approaches have been used in addressing this challenge. In this review, we aimed to identify the most common data 
reporting methods for handling cases of multiple injuries in longitudinal studies of team ball sport participants. Our key finding was that in half of all studies that extend for more than one year/season, the number of injuries or injured athletes was pooled (grouped) over the whole time period and reported as an overall total. In other words, the occurrence of multiple injuries was not explicitly reported despite these same studies having collected data at an individual level-one of our inclusion criteria for the review. Of the studies that did report multiple injuries, many were limited to inclusion of recurrent injuries only (i.e. those of the exact same type and at the same site). Very few authors have recorded and reported multiple injuries of differing natures and they have largely done so using inconsistent methods across studies that prevented an in-depth comparison of the results or strong conclusions on the likelihood of athletes experiencing subsequent injury.

\subsection{Understanding the Current Limitations in Injury Reporting}

The most common presentation of data was pooled injury counts summarised across teams/seasons. This is problematic if there is no indication of the number of athletes sustaining more than one injury, particularly in studies aiming to infer injury risk. Although many of the included studies did not have a primary aim to look at more than one injury in individuals, the issue still needs to be considered. For example, a common study aim might be to follow specific teams/squads to determine changes in team outcomes based on new training practices. Similarly, schoollevel sport competitions may be interested in how overall safety levels change over time, not individual risks. However, when reporting injury incidence for an understanding of injury risk, the individual distribution of the number of injuries is important because of its impact on the correct statistical reporting of incidence rates [17]. As an example, one study reported 134 injuries in 268 athletes over 3 years "yielding a risk of injury of $50 \%$ " [38] (p148). Such a statement is only true if there were no athletes with more than one injury within the study population. As the authors did not report the distribution of injuries by participants, it is not possible to verify this but, in general, findings reported in this manner will miss details that are vital for interpreting results. In its most simplistic form, this information is depicted in Fig. 2, reporting scenario A. It can be seen that the incidence outcomes within this scenario (10 athletes included, with 20 injuries in total) are similar for both seasons, although the actual situation is very different (refer to the numbers in black circles).

Where the potential for an individual having more than one injury in the results was recognised, this was sometimes addressed by reporting the range of injuries sustained or the maximum number of injuries sustained by an individual, e.g. 'between one and $n$ injuries occurred'. Other authors acknowledged the problem of multiple injuries by reporting the mean and standard deviation for injuries per athlete/team per season (e.g. "On average, an athlete incurred $3.6 \pm 0.7$ injuries" [39]). Figure 2, reporting scenario B, shows that these approaches still fail to adequately address how an individual with more than one injury impacts the group result as it can again be seen that incidence outcomes using this scenario are similar for both seasons (range 0-9 injuries; maximum: 9; mean: 2 injuries per athlete per year), although the actual situation is very different (refer again to the numbers in black circles).

It was clear that many cohort participants within the reviewed studies had likely experienced more than one injury (i.e. where the number of injuries recorded exceeded the number of injured participants). This is common in studies of sports injury. Similarly, the number of injured athletes is often less than the number of athletes included, as can be seen in Table 2. In other words, injury data in team sports are commonly skewed, with a large number of zero counts, and this distribution needs to be considered [17]. One, or just a few athletes, might sustain the majority of team injuries [15, 28], as shown in Fig. 2, scenario C. For any team, at any time point, the proportion of athletes contributing to the injury count will differ. Therefore, even those studies reporting team-level data and overall changes in annual injury counts (and not necessarily concerned by any individual outcomes) still need to consider individual bias in the results.

Irrespective of whether a simple or complex study design and analysis method is chosen to meet a study's aim, authors must clearly identify the relevant details of included variable characteristics as they relate to multiple injuries. As a minimum, the frequency distribution of the number of injuries is recommended for inclusion in future work (see example in Finch and Cook [15]). This information would at least enable readers to gain a sense of the individual burden and scope for potential dependency between multiple injuries sustained, as well as providing crucial support for the choice of statistical modelling applied (e.g. if there is overdispersion of data or a high number of zero counts) [17, 40]. This more detailed presentation of the data is similar to recommendations of analyses where time to injury data is considered, with improved reporting of assumptions and detailing of the event being modelled [7, 41].

\subsection{Other Findings Identified from the Review}

A key finding was that the majority of studies presented broad annual injury rates across teams/seasons. Few gave specific reasoning as to why the results were presented in 
Fig. 2 Different reporting scenarios for injuries in a fictional team of 10 athletes followed for two consecutive seasons. Black circles indicate that athletes were included in the team during the season, white circles indicate that athletes were not included in the team during the season, and the number in circle indicates the number of injuries in the specified timeframe

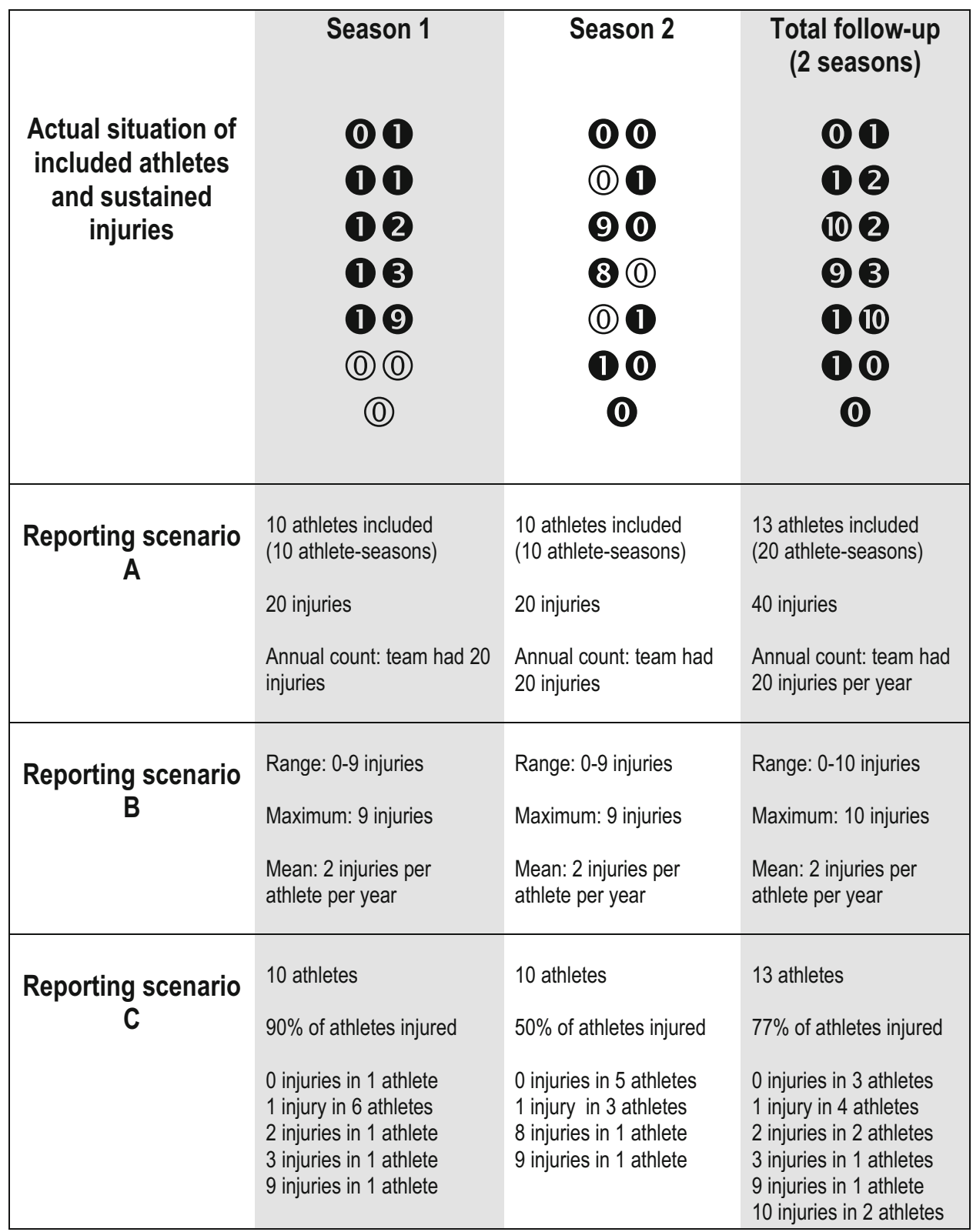

this way, with the exception of an aim being to compare year-to-year outcomes. One study team reported that results in two of their publications were both pooled as there was no statistically significant change over time $[29,37]$. Reasons why pooled data may be favoured by researchers could include the avoidance of difficulties with ethical approval if data are reported at a group level not an individual level; a need for confidentiality, as pooling the data hides small or distinctive values; the analysis is less complicated if data are grouped; pooling data will give larger numbers, allowing for more sophisticated analyses; or to avoid the difficulties in differentiating between index/ recurrent/subsequent injuries. While the results across studies were presented largely as pooled data at the team level, the collection of data itself was at an individual level, with some form of identifier in the data collection process a requirement of our study inclusion process. Based on these studies, it would seem that it is easier to record, rather than adequately report, more than one injury within study cohort members.

The overall number of publications extending beyond one season/year has increased over the last 2-3 years. This possibly reflects a growing understanding of the need to look not only beyond one season when considering injury risk but also new validated technology to facilitate longterm data collection. For example, recent studies document the value of online applications and SMS text messaging in enabling a relative ease of access and follow-up of 
participants [42, 43]. Online and automated forms of data collection will be further enhanced in coming years if analytical methods and reporting algorithms that make the most of individual-level data also become widely used.

A limitation of the current understanding about multiple injuries in the reviewed studies is the focus being largely limited to recurrent injuries-injuries that are exactly the same site and same type as previously incurred by an individual. Clinical experience and new classification models substantiate the need to look at the relationships between injuries more broadly [15]. Another barrier to reporting multiple injuries is how to document and measure recovery. Recovery is a key element in determining whether a subsequent injury is new or potentially related to a previous occurrence. Unlike other injury contexts, the risk of more than one injury in the sports setting is high and there can be a short time lag between the injury events. Within this review, we have not identified and reported how recovery was defined or addressed, although the importance of this topic and its relation to reporting multiple injuries is acknowledged. We initially attempted to include the information but found the message confused our primary aim of reporting methods of multiple injuries. What was clear in terms of recovery was that authors mostly used a return-to-sport definition, with or without clearance from a medical specialist and at differing levels (i.e. training, partial return to competition, or full return to competition). Operationalising 'return to sport' as an outcome measure is challenging [44, 45] and, indeed, there is an entire consensus statement developed for this specific issue [46]. With the exception of the date of return, recovery from injury as a clearly defined outcome currently lacks universal objective measures and is influenced by a range of potential factors, including access to medical care and previously sustained injuries [44-46]. A second challenge in defining recovery arises with the recent expansion of more inclusive injury definitions that are no longer consistent with earlier recovery definitions. For example, if a holistic approach is used in a definition, such as 'recordable incidents inclusive of psychological factors'[47], then it is not clear how concepts of readiness, fear and confidence contribute to recovery and return-toplay definitions. The ongoing discussion among researchers, and proposed methods for addressing this topic, are promising and will only serve to improve not only an understanding of recovery but also, in turn, multiple injuries.

\subsection{Limitations of the Review}

We included all studies where it was clearly stated that an individual unique code had been assigned to identify each included athlete, in which case an individual injury history could theoretically have been traced over the duration of the study. Despite a conservative approach to excluding papers, referring to the full text for information in order to be certain of exclusions, there remains a possibility of having missed papers owing to the challenges of identifying and interpreting authors' methods for inclusion and recording of injury data. In particular, it was often unclear from the identified studies whether individual data were available based on the described methods of data collection. Nevertheless, it is likely we have captured a highly representative sample of the majority of publications that have adopted the most commonly used methods in the general team ball sports injury research literature. Future work could consider multiple injuries in individual sports and determine whether reporting in this setting is different. It would also be worth assessing if there is better or worse capture of overuse injuries than the more traumatic, time-loss injuries, which tend to feature more heavily in team ball sport research, and determining whether this is due to data collection methods or true prevalence. Although the inclusion criteria specified that all injury types were to be captured by the studies (i.e. excluding studies of one injury type only), the delineation between injury types (traumatic, overuse) was not the focus of our results. As our conclusions are in relation to the reporting of injury counts only, they will apply equally to different injury types and also to non-team ball sports.

We chose to limit our studies to those of more than one season/year duration as an increased number of injuries is likely over increased time and we were interested in how researchers handled this methodologically. However, with this length of time it was not always clear how many individuals were followed. It is possible that in some studies, none, or very few individuals were followed up, as was the case with statements such as "only 45 players $(7 \%)$ were present in both years" [37] (p. 277). In some instances, authors reported the number of people who played each of the seasons whether or not they were injured, information that would be valuable to include in future studies. As examples, one study reported the number of athletes for each subsequent season as "thirty six players were followed for one season, 163 for two seasons, 701 for three seasons, 412 for four seasons and 171 for five or six seasons" [48] (p. 464). Similarly, in other papers, authors reported "the average player was in the database for $3.7 \pm 3.2$ seasons" [26] (p. 286) and 56 of 472 $(12 \%)$ athletes were included for the full duration of the study [49]. Our study findings are thus limited by the data reported in the original studies as we cannot be sure how many individuals were followed-up for a given length of time. 


\section{Conclusions}

Limitations associated with the data that have been reported in previous sports-injury epidemiological studies have significantly hindered the ability to provide robust evidence about subsequent injuries. While differences in wording and definitions used for injuries, recovery, exacerbation, recurrence and so forth may seem inconsequential at times, their influence is far reaching [50], with differences affecting the accuracy of both the classification of injuries and calculation of injury incidence. This in turn limits our understanding of risk factors for injury.

Sports medicine research is not far from realising the collection and analysis of data that identify individual multiple injury occurrences, although the gap that remains may be challenging to bridge. Collaboration between different professions (clinicians, epidemiologists and biostatisticians) early in the design of a study will help to address some of these challenges. Ultimately, injury prevention efforts rely on accurate incidence estimates, and ongoing developments in this area are encouraged in order to advance understanding of the causal underpinnings of sports injuries and their prevention.

\section{Compliance with Ethical Standards}

Funding No sources of funding were used to assist in the preparation of this article.

Conflicts of interest Lauren Fortington, Henk van der Worp, Inge van den Akker-Scheek and Caroline Finch declare that they have no conflicts of interest relevant to the content of this review.

Open Access This article is distributed under the terms of the Creative Commons Attribution 4.0 International License (http:// creativecommons.org/licenses/by/4.0/), which permits unrestricted use, distribution, and reproduction in any medium, provided you give appropriate credit to the original author(s) and the source, provide a link to the Creative Commons license, and indicate if changes were made.

\section{References}

1. Hägglund $M$, Waldén $M$, Magnusson $H$, et al. Injuries affect team performance negatively in professional football: an 11-year follow-up of the UEFA Champions League injury study. Br J Sports Med. 2013;47:738-42.

2. Arnason A, Sigurdsson SB, Gudmundsson A, et al. Physical fitness, injuries, and team performance in soccer. Med Sci Sports Exerc. 2004;36:278-85.

3. Finch C, Owen N, Price R. Current injury or disability as a barrier to being more physically active. Med Sci Sports Exerc. 2001;33:778-82.

4. Finch C. A new framework for research leading to sports injury prevention. J Sci Med Sport. 2006;9:3-9.
5. van Mechelen W, Hlobil H, Kemper H. Incidence, severity, aetiology and prevention of sports injuries: a review of concepts. Sports Med. 1992;14:82-99.

6. Shrier I, Steele RJ, Hanley J, et al. Analyses of injury count data: some do's and don'ts. Am J Epidemiol. 2009;170:1307-15.

7. Finch CF, Marshall SW. Let us stop throwing out the baby with the bathwater: towards better analysis of longitudinal injury data. Br J Sports Med. 2016;50(12):712-5.

8. Finch CF. An overview of some definitional issues for sports injury surveillance. Sports Med. 1997;24:157-63.

9. King DA, Gabbett TJ, Gissane C, et al. Epidemiological studies of injuries in rugby league: suggestions for definitions, data collection and reporting methods. J Sci Med Sport. 2009;12:12-9.

10. Fuller CW, Molloy MG, Bagate C, et al. Consensus statement on injury definitions and data collection procedures for studies of injuries in rugby union. Br J Sports Med. 2007;41:328-31.

11. Fuller CW, Ekstrand J, Junge A, et al. Consensus statement on injury definitions and data collection procedures in studies of football (soccer) injuries. Br J Sports Med. 2006;40:193-201.

12. Knowles SB, Marshall SW, Guskiewicz KM. Issues in estimating risks and rates in sports injury research. J Athl Training. 2006;41:207-15.

13. Brooks JHM, Fuller CW. The influence of methodological issues on the results and conclusions from epidemiological studies of sports injuries: illustrative examples. Sports Med. 2006;36:459-72.

14. Phillips LH. Sports injury incidence. $\mathrm{Br} \mathrm{J}$ Sports Med. 2000;34(2):133-6.

15. Finch CF, Cook J. Categorising sports injuries in epidemiological studies: the subsequent injury categorisation (SIC) model to address multiple, recurrent and exacerbation of injuries. $\mathrm{Br} \mathrm{J}$ Sports Med. 2014;48:1276-80.

16. Hamilton GM, Meeuwisse WH, Emery CA, et al. Subsequent injury definition, classification and consequence. Clin J Sport Med. 2011;21:508-14.

17. Ullah S, Finch CF, Day L. Statistical modelling for falls count data. Acc Anal Prev. 2010;42:384-92.

18. Ullah S, Gabbett TJ, Finch CF. Statistical modelling for recurrent events: an application to sports injuries. Br J Sports Med. 2014;48:1287-93.

19. Finch CF, Cook J, Gabbe BJ, et al. A new way of categorising recurrent, repeat and multiple sports injuries for injury incidence studies: the subsequent injury categorisation (SIC) model. Australas Epidemiol. 2015;22:22-5.

20. de Visser HM, Reijman M, Heijboer MP, et al. Risk factors of recurrent hamstring injuries: a systematic review. Br J Sports Med. 2012;46:124-30.

21. Fortington LV, Berry J, Buttifant D, et al. Shorter time to first injury in first year professional football players: a cross-club comparison in the Australian Football League. J Sci Med Sport. 2016;19:18-23.

22. Videbæk S, Bueno AM, Nielsen RO, et al. Incidence of runningrelated injuries per $1000 \mathrm{~h}$ of running in different types of runners: a systematic review and meta-analysis. Sports Med. 2015;45:1017-26.

23. Timpka T, Jacobsson J, Bickenbach J, et al. What is a sports injury? Sports Med. 2014;44:423-8.

24. Carling C, McCall A, Le Gall F, et al. The impact of short periods of match congestion on injury risk and patterns in an elite football club. Br J Sports Med. 2016;50(12):764-8.

25. Ramirez M, Schaffer KB, Shen H, et al. Injuries to high school football athletes in California. Am $\mathrm{J}$ Sports Med. 2006;34:1147-58. 
26. Drakos MC, Domb B, Starkey C, et al. Injury in the National Basketball Association: a 17-year overview. Sports Health. 2010;2:284-90.

27. Le Gall F, Carling C, Reilly T. Injuries in young elite female soccer players: an 8-season prospective study. Am J Sports Med. 2008;36:276-84.

28. Rauh MJ, Macera CA, Ji M, et al. Subsequent injury patterns in girls' high school sports. J Athl Training. 2007;42:486-94.

29. Turbeville SD, Cowan LD, Owen WL, et al. Risk factors for injury in high school football players. Am J Sports Med. 2003;31:974-80.

30. Deehan DJ, Bell K, McCaskie AW. Adolescent musculoskeletal injuries in a football academy. Bone Joint J. 2007;89-B:5-8.

31. Ortega-Gallo PO, Argemi R, Batista J, et al. The epidemiology of injuries in a professional soccer team in Argentina. Int Sport Med J. 2006;7:255-65.

32. Pastor MF, Ezechieli M, Claassen L, et al. Prospective study of injury in volleyball players: 6 year results. Technol Health Care. 2015;23:637-43.

33. van der Sluis A, Elferink-Gemser MT, Coelho-e-Silva MJ, et al. Sport injuries aligned to peak height velocity in talented pubertal soccer players. Int J Sports Med. 2014;35:351-5.

34. Dupont G, Nedelec M, McCall A, et al. Effect of 2 soccer matches in a week on physical performance and injury rate. Am J Sports Med. 2010;38:1752-8.

35. Dompier TP, Powell JW, Barron MJ, et al. Time-loss and nontime-loss injuries in youth football players. J Athl Training. 2007;42:395-402.

36. Hägglund M, Walden M, Ekstrand J. Previous injury as a risk factor for injury in elite football: a prospective study over two consecutive seasons. Br J Sports Med. 2006;40:767-72.

37. Turbeville SD, Cowan LD, Asal NR, et al. Risk factors for injury in middle school football players. Am J Sports Med. 2003:31:276-81.

38. Barber-Foss KD, Myer GD, Hewett TE. Epidemiology of basketball, soccer, and volleyball injuries in middle-school female athletes. Phys Sports Med. 2014;42:146-53.

39. Mallo J, González $P$, Veiga $S$, et al. Injury incidence in a Spanish sub-elite professional football team: a prospective study during four consecutive seasons. J Sports Sci Med. 2011;10:731-6.

40. Casals M, Langohr K, Carrasco JL, et al. Parameter estimation of Poisson generalized linear mixed models based on three different statistical principles: a simulation study. SORT-Stat Oper Res T. 2015;39:281-308.

41. Amorim LDAF, Cai J. Modelling recurrent events: a tutorial for analysis in epidemiology. Int J Epidemiol. 2015;44:324-33.

42. Ekegren C, Donaldson A, Gabbe B, et al. Implementing injury surveillance systems alongside injury prevention programs: evaluation of an online surveillance system in a community setting. Inj Epidemiol. 2014;1:19.

43. Moller M, Attermann J, Myklebust G, et al. Injury risk in Danish youth and senior elite handball using a new SMS text messages approach. Br J Sports Med. 2012;46:531-7.

44. Shrier I, Safai P, Charland L. Return to play following injury: whose decision should it be? $\mathrm{Br} \mathrm{J}$ Sports Med. 2014:48:394-401

45. Creighton DW, Shrier I, Shultz R, et al. Return-to-play in sport: a decision-based model. Clin J Sport Med. 2010;20:379-85.

46. Herring SA, Kibler WB, Putukian M. The team physician and the return-to-play decision: a consensus statement-2012 update. Med Sci Sports Exerc. 2012;44:2446-8.

47. Timpka T, Alonso J-M, Jacobsson J, et al. Injury and illness definitions and data collection procedures for use in epidemiological studies in athletics (track and field): consensus statement. Br J Sports Med. 2014;48:483-90.
48. Kucera KL, Marshall SW, Kirkendall DT, et al. Injury history as a risk factor for incident injury in youth soccer. Br J Sports Med. 2005;39:462-6.

49. Palmer-Green DS, Stokes KA, Fuller CW, et al. Training activities and injuries in English youth academy and schools rugby union. Am J Sports Med. 2015;43:475-81.

50. Kluitenberg B, van Middelkoop M, Verhagen E, et al. The impact of injury definition on injury surveillance in novice runners. J Sci Med Sports. 2016;19(6):470-5.

51. Dagiau RF, Dillman CJ, Milner EK. Relationship between exposure time and injury in football. Am J Sports Med. 1980;8:257-60.

52. Canale ST, Cantler ED, Sisk TD, et al. A chronicle of injuries of an American intercollegiate football team. Am J Sports Med. 1981;9:384-9.

53. Zelisko JA, Noble HB, Porter M. A comparison of men's and women's professional basketball injuries. Am J Sports Med. 1982;10:297-9.

54. Orchard J, Wood T, Seward H, et al. Comparison of injuries in elite senior and junior Australian football. J Sci Med Sports. 1998;1:82-8.

55. Hawkins RD, Fuller CW. A prospective epidemiological study of injuries in four English professional football clubs. Br J Sports Med. 1999;33:196-203.

56. Powell JW, Barber-Foss KD. Injury patterns in selected high school sports: a review of the 1995-1997 seasons. J Athl Training. 1999;34:277-84.

57. Meeuwisse WH, Hagel BE, Mohtadi NG, et al. The distribution of injuries in men's Canada West university football. A 5-year analysis. Am J Sports Med. 2000;28:516-23.

58. Powell JW, Barber-Foss KD. Sex-related injury patterns among selected high school sports. Am J Sports Med. 2000;28:385-91.

59. Starkey C. Injuries and illnesses in the National Basketball Association: a 10-year perspective. $\mathrm{J}$ Athl Training. 2000;35:161-7.

60. Gunnoe AJ, Horodyski M, Tennant LK, et al. The effect of life events on incidence of injury in high school football players. J Athl Training. 2001;36:150-5.

61. Hawkins RD, Hulse MA, Wilkinson C, et al. The association football medical research programme: an audit of injuries in professional football. Br J Sports Med. 2001;35:43-7.

62. Watson AWS. Sports injuries related to flexibility, posture, acceleration, clinical defects, and previous injury, in high-level players of body contact sports. Int J Sports Med. 2001;22:222-5.

63. Drawer S, Fuller CW. Evaluating the level of injury in English professional football using a risk based assessment process. Br J Sports Med. 2002;36:446-51.

64. Orchard JW, Seward HG. Epidemiology of injuries in the Australian Football League, seasons 1997-2000. Br J Sports Med. 2002;36:39-45.

65. Gabbett TJ. Incidence of injury in semi-professional rugby league players. Br J Sports Med. 2003;37:36-44.

66. Meeuwisse WH, Sellmer R, Hagel BE. Rates and risks of injury during intercollegiate basketball. Am J Sports Med. 2003;31:379-85.

67. McManus A, Stevenson M, Finch CF, et al. Incidence and risk factors for injury in non-elite Australian Football. J Sci Med Sport. 2004;7:384-91.

68. Powell JW, Dompier TP. Analysis of injury rates and treatment patterns for time-loss and non-time loss injuries among collegiate student-athletes. J Athl Training. 2004;39:56-70.

69. Price R, Hawkins R, Hulse M, et al. The football association medical research programme: an audit of injuries in academy youth football. Br J Sports Med. 2004;38:466-71.

70. Giza E, Mithofer K, Farrell L, et al. Injuries in women's professional soccer. Br J Sports Med. 2005;39:212-6. 
71. Le Gall F, Carling C, Reilly T, et al. Incidence of injuries in elite French youth soccer players: a 10-season study. Am J Sports Med. 2006;34:928-38.

72. McManus A, Stevenson MR, Finch CF. Incidence and risk factors for injury in non-elite netball. J Sci Med Sport. 2006;9:119-24.

73. Merron R, Selfe J, Swire R, et al. Injuries among professional soccer players of different age groups: a prospective four-year study in an English Premier League Football Club. Int Sport Med J. 2006;7:266-76.

74. Brooks JH, Fuller CW, Kemp SP, et al. An assessment of training volume in professional rugby union and its impact on the incidence, severity, and nature of match and training injuries. J Sports Sci. 2008;26:863-73.

75. Johnson AF, Doherty P, Freemont A. Investigation of growth, development, and factors associated with injury in elite schoolboy footballers: prospective study. BMJ. 2009;338:b490.

76. Knowles SB, Marshall SW, Bowling MJ, et al. Risk factors for injury among high school football players. Epidemiology. 2009;20:302-10.

77. Dauty M, Collon S. Incidence of injuries in French professional soccer players. Int J Sports Med. 2011;32:965-9.

78. Mallo J, Dellal A. Injury risk in professional football players with special reference to the playing position and training periodization. J Sports Med Phys Fitness. 2012;52:631-8.

79. Murphy JC, O'Malley E, Gissane C, et al. Incidence of injury in Gaelic football: a 4-year prospective study. Am J Sports Med. 2012;40:2113-20.

80. Chalmers S, Magarey ME, Esterman A, et al. The relationship between pre-season fitness testing and injury in elite junior Australian football players. J Sci Med Sport. 2013;16:307-11.

81. Eirale C, Tol JL, Smiley F, et al. Does Ramadan affect the risk of injury in professional football? Clin J Sports Med. 2013;23:261-6.

82. Ekstrand J, Hägglund M, Kristenson K, et al. Fewer ligament injuries but no preventive effect on muscle injuries and severe injuries: an 11-year follow-up of the UEFA Champions League injury study. Br J Sports Med. 2013;47:732-7.

83. Grooms DR, Palmer T, Onate JA, et al. Comprehensive soccerspecific warm-up and lower extremity injury collegiate male soccer players. J Athl Training. 2013;48(6):782-9.

84. Malisoux L, Frisch A, Urhausen A, et al. Injury incidence in a sports school during a 3-year follow-up. Knee Surg Sports Traumatol Arthrosc. 2013;21:2895-900.

85. Peck KY, Johnston DA, Owens BD, et al. The incidence of injury among male and female intercollegiate rugby players. Sports Health. 2013;5:327-33.

86. Tourny C, Sangnier S, Cotte T, et al. Epidemiologic study of young soccer player's injuries in U12 to U20. J Sports Med Phys Fitness. 2014;54:526-35.

87. Barron MJ, Branta CF, Powell JW, et al. Effects of an injury prevention program on injury rates in American youth football. Int J Sports Sci Coach. 2014;9:1227-40.
88. Bjørneboe J, Bahr R, Andersen TE. Gradual increase in the risk of match injury in Norwegian male professional football: a 6-year prospective study. Scand J Med Sci Sports. 2014;24:189-96.

89. Mohib M, Moser N, Kim R, et al. A four year prospective study of injuries in elite Ontario youth provincial and national soccer players during training and matchplay. J Can Chiropr Assoc. 2014;58:369-76.

90. Carling C, McCall A, Le Gall F, et al. The impact of in-season national team soccer play on injury and player availability in a professional club. J Sports Sci. 2015;33:1751-7.

91. Dompier TP, Marshall SW, Kerr ZY, et al. The National athletic treatment, injury and outcomes network (NATION): methods of the surveillance program, 2011-2012 through 2013-2014. J Athl Train. 2015;50:862-9.

92. Ekegren CL, Gabbe BJ, Donaldson A, et al. Injuries in community-level Australian football: results from a club-based injury surveillance system. J Sci Med Sports. 2015;18:651-5.

93. Gastin PB, Meyer D, Huntsman E, et al. Increase in injury risk with low body mass and aerobic-running fitness in elite Australian football. Int J Sports Physiol Perform. 2015;10:458-63.

94. Kerr ZY, Marshall SW, Simon JE, et al. Injury rates in age-only versus age-and-weight playing standard conditions in American youth football. Orthop J Sports Med. 2015;3:2325967115603979.

95. Kristenson K, Bjørneboe J, Waldén M, et al. Injuries in male professional football: a prospective comparison between individual and team-based exposure registration. Scand J Med Sci Sports. 2016;26(10):1225-32.

96. Laux P, Krumm B, Diers M, et al. Recovery-stress balance and injury risk in professional football players: a prospective study. J Sports Sci. 2015;33:2140-8.

97. Lawrence DW, Hutchison MG, Comper P. Descriptive epidemiology of musculoskeletal injuries and concussions in the National Football League, 2012-2014. Orthop J Sports Med. 2015;3:2325967115583653.

98. Massidda M, Corrias L, Bachis V, et al. Vitamin D receptor gene polymorphisms and musculoskeletal injuries in professional football players. Exp Ther Med. 2015;9:1974-8.

99. Owen AL, Forsyth JJ, Wong DP, et al. Heart rate-based training intensity and its impact on injury incidence among elite-level professional soccer players. J Strength Cond Res. 2015;29:1705-12.

100. Reeser JC, Gregory A, Berg RL, et al. A comparison of women's collegiate and girls' high school volleyball injury data collected prospectively over a 4-year period. Sports Health. 2015;7:504-10.

101. Williams S, Trewartha G, Kemp SPT, et al. Time loss injuries compromise team success in Elite Rugby Union: a 7-year prospective study. Br J Sports Med. 2016;50(11):651-6.

102. Hulin BT, Gabbett TJ, Lawson DW, et al. The acute:chronic workload ratio predicts injury: high chronic workload may decrease injury risk in elite rugby league players. Br J Sports Med. 2016;50:231-6. 